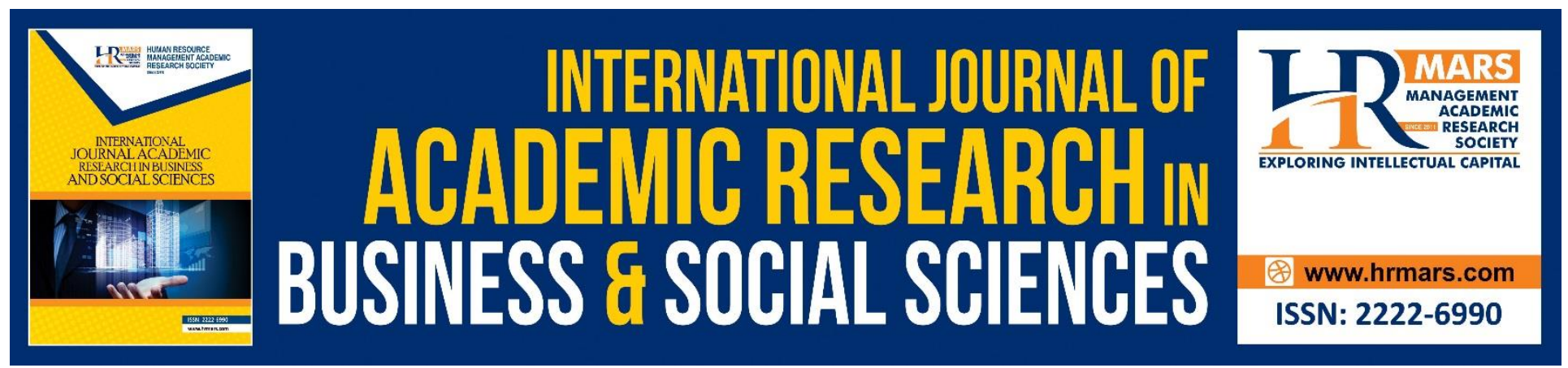

\title{
Bee Venom Therapy: An Ethical of Islamic Perspective
}

\section{Fathullah Asni, Mohammad Amir Wan Harun}

To Link this Article: http://dx.doi.org/10.6007/IJARBSS/v10-i11/7947

DOI:10.6007/IJARBSS/v10-i11/7947

Received: 04 September 2020, Revised: 28 September 2020, Accepted: 25 October 2020

Published Online: 12 November 2020

In-Text Citation: (Asni, \& Harun, 2020)

To Cite this Article: Asni, F., \& Harun, M. A. W. (2020). Bee Venom Therapy: An Ethical of Islamic Perspective. International Journal of Academic Research in Business and Social Sciences. 10(11), 174-179.

Copyright: (c) 2020 The Author(s)

Published by Human Resource Management Academic Research Society (www.hrmars.com)

This article is published under the Creative Commons Attribution (CC BY 4.0) license. Anyone may reproduce, distribute, translate and create derivative works of this article (for both commercial and non-commercial purposes), subject to full attribution to the original publication and authors. The full terms of this license may be seen

at: http://creativecommons.org/licences/by/4.0/legalcode

Vol. 10, No. 11, 2020, Pg. 174 - 179

http://hrmars.com/index.php/pages/detail/IJARBSS

JOURNAL HOMEPAGE

Full Terms \& Conditions of access and use can be found at http://hrmars.com/index.php/pages/detail/publication-ethics 


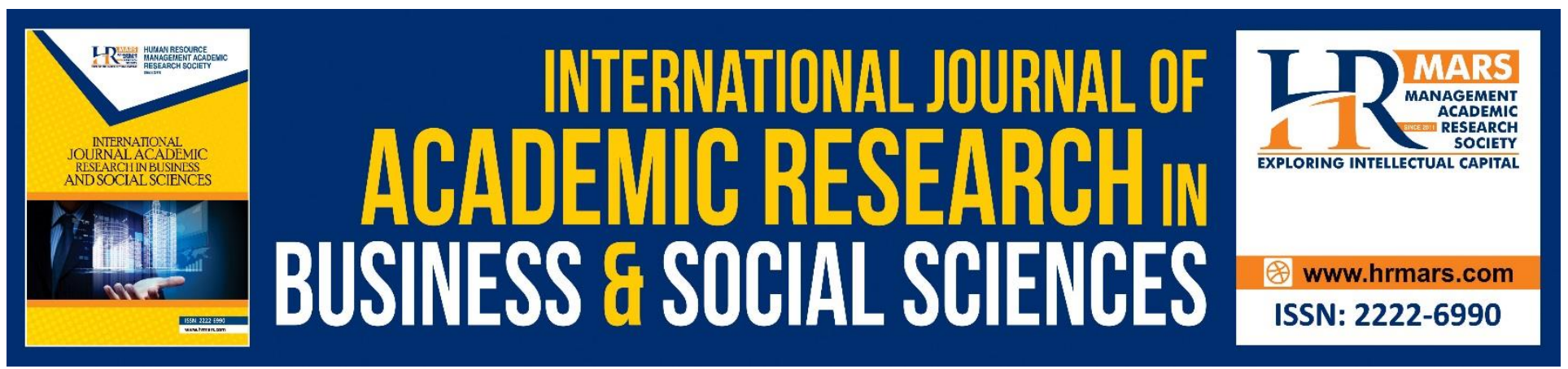

\title{
Bee Venom Therapy: An Ethical of Islamic Perspective
}

\author{
Fathullah Asni \\ Faculty of Islamic Studies, Kolej Universiti Islam Perlis, Malaysia \\ Email: fathullah@kuips.edu.my \\ Mohammad Amir Wan Harun \\ School of Humanities, Universiti Sains Malaysia, Malaysia \\ Email: amirwan@usm.my
}

\begin{abstract}
Bee venom therapy (BVT) is one of the traditional methods of medicine that has been practiced since 1000-3000 BC. BVT has been used for many diseases, especially rheumatoid arthritis, Parkinson's disease, and others in clinical treatment. However, this treatment method has raised questions based on the Prophet's hadith which stated Islam as a religion that forbids the killing of bees as a result of using their venom. Therefore, this paper aims to study the practice of BVT from the ethical point of Islamic treatment. This qualitative study collected its data through library research, i.e. by referring to Islamic ethics therapy and BVT practices from books and journals. The data were analysed using document and content analysis. The study found that Islamic ethics treatment permitted the treatment of bee venom (BV) with four conditions, namely get advice from a medical professional, no alternative medicine for the disease encountered, treatment only when needed, and no allergic reaction to BV. This is because some studies are claiming that BVT can gives adverse effects on patients if there is no guidance provided by a specialist. Therefore, the advice of a specialist in BVT is important to prevent any harm to the patient.
\end{abstract}

Keywords: Bee Venom, Bee Venom Therapy, Islamic Ethics Therapy.

\section{Introduction}

Bee venom therapy (BVT) is the therapeutic application of bee venom (BV) into the body for the treatment of diseases, which has been used in traditional oriental medicine since 1000-3000 BCE (Park et al., 2004). As a complementary and alternative medicine approach, BVT is applied through direct bee sting or injection of BV extracted by an electric stimulus. In the beginning, the use of BVT is based on the fact that beekeepers (who often get stung) are very rarely suffering from arthritis or troubles with their joints and muscles (Zhang et al., 2018). However, it had not been widely used until year 1888, when a book was published and reported on a peculiar connection between the bee stings and rheumatism. Subsequently, Dr. Bodog F. Beck introduced this therapeutic method to more BVT 
INTERNATIONAL JOURNAL OF ACADEMIC RESEARCH IN BUSINESS AND SOCIAL SCIENCES Vol. 10, No. 11, 2020, E-ISSN: 2222-6990 @ 2020 HRMARS

users (Zhang et al., 2018), which then turned to be increasingly popular after being claimed as capable to cure critical illnesses such as cancer and HIV (Orsolic, 2012).

However, in treatment involving BV, the bee would be dead after releasing the venom and the use of $\mathrm{BV}$ as a treatment method is categorised as a poison. This raises the question of the ethical aspects of Islamic treatment, of what is its view of BVT that leads to bee death and the use of BV in medicinal therapy. Meanwhile, there is a clear hadith about the ban on killing bees and using harmful substances for treatment purposes. Therefore, this study aims to examine the ethical view of Islamic treatment of BVT practices.

There are many previous studies that focused on the potential and side effects of using BVT. This was done by Zhang et al. (2018), which stated BVT as a method of clinical treatment that has been used for many diseases, especially rheumatoid arthritis, Parkinson's disease, and others. Besides, the researchers also highlight BVT as having a possibility that could cause to many negative effects such as systemic reactions, skin problems and nonspecific reactions. On the other hand, a study conducted by Orsolic's (2012) has found that BVT can kill cancer cells. Based on the details, the researchers found that the BVT study has not been done in thorough perspective. Therefore, this paper aims to study the method of BVT from the ethical Islamic treatment point of view.

\section{Literature Research}

Ethics is derived from the Greek word 'ethos', which signifies behaviour as an element that is determined by attitude and custom. Ethics is known as a moral principle that govern a person's behaviour, and it is closely related to human actions, whether right or wrong, good or bad. Ethics is also an act that leads to good things like justice (Daud, 1996). In Islam, ethics is a human behaviour that is accepted as the norm, as long as it does not violate the law of Islam (Khairuldin et al., 2019). According to Sahad and Asni (2018), ethics is defined as the guideline for determining good and bad behaviour of individuals.

From the Islamic ethical treatment point of view, Islam does not prevent its believers from undergoing any traditional treatment as long as it does not conflict or against with Shariah (Islamic law). It can be concluded that compliance with Shariah in the matter of treatment is an ethic in Islamic treatment (Gatrad \& Sheikh, 2001). Thus, Muslims can get benefited from medicines which gather from halal sources that include both traditional and modern methods (Shaharom, 2008). However, there are a few substances in treatment that are prohibited by Islam, especially those that include illegal and impure (najis) substances such as blood, carcasses, pigs, dogs, and liquids or alcohol (Shaharom, 2008). Based on the Islamic view regarding the use of animal venom as a treatment, the original law is identified as illegal based on the hadith of the Prophet (PBUH), which stated that "whoever drinks (benefits) the venom, he is killed by the venom, then the venom will be by his side on the Day of Judgment and he will drink it at hell for an indefinite period" (al-Bukhari, 1422H). However, if it can be proven that if the venom can cure the disease, then it has the exception, where the majority of scholars including Hanafi, Maliki, Shafi'i and Hanbali allowed its application as part of treatments (Ibn Qudamah, 1405H).

Also, according to al-Mubarakfuri (n.d.), if venom can be used in medicine, it is allowed by Sharak on condition of obtaining the consent of a medical professional. Similarly, according to Ibn Qudamah $(1405 \mathrm{H})$, some venoms can be used for medical purposes, as long as they are naturally beneficial and healable. However, if they can be naturally harmful, then it would be straightly prohibited and not 
INTERNATIONAL JOURNAL OF ACADEMIC RESEARCH IN BUSINESS AND SOCIAL SCIENCES Vol. 10, No. 11, 2020, E-ISSN: 2222-6990 @ 2020 HRMARS

be allowed by Sharak. This indicates that the Sharak law allowed venom to be a therapy, as long as it had the approval of the medical professional.

\section{Methodology}

This study uses document analysis to obtain data. According to Jasmi (2012), document analysis is a method of obtaining relevant information from printed material in the form of documents. Hence, the researchers conduct document analysis by reviewing journals and books on BVT and Islamic ethics treatment. The data collected will be analysed using content analysis method. According to Yusof (2004), content analysis is one of research techniques that is implemented by concluding systematically and objectively based on the data obtained in the form of documents. Accordingly, based on research on the collected data, the researchers will conduct an analysis on BVT, by narrowing its focus on the ethics of Islamic treatment perspective.

\section{Result and Discussion}

Based on previous studies, it has been found that BVT can cause bee death after the sting is released right after the insertion of venom (Zia \& Muhammad, 2017). This seems to be contrary to the proposition of the hadith of the Prophet (PBUH) which prohibits the killing of four kinds of animals, namely ants, bees, hud-hud (bird's name) and surad (bird's name) (Ibn Hanbal, 2001). Hence, based on this hadith according to al-Nawawi (n.d.), it is banned to kill animals as per mentioned above, which obviously stated bee as one among the list. To be precise, it is banned for causing harm to the natural ecosystem that leads bees to be killed during the therapy procedure, as in the word of Allah the Almighty in Surah al-Baqarah verse 205 which stated, "when he turns his back, His aim everywhere is to spread mischief through the earth and destroy crops and cattle. But Allah loveth not mischief." This is supported by a study of Shipp et al. (1994) which stated that bees can increase plant fertility and increase fruit yield in terms of number and quality. Bees also provided several benefits to humans, and this can be found through the production of honey, beeswax, pollen, royal jelly, and propolis (Mizrahi \& Lensky, 2013). The finding is also supported by a study conducted by Blaauw and Isaacs (2014).

However, the bee can be killed if it causes harm to people; for an example, if bees are nesting too much in a residential area and can be harmful to humans, it can be killed as stated in the fiqh method which means, "harm is to be eliminated" (Ibn Qudamah, 1405H). Similarly, if a person is in a state of darurah (necessity) and hajah (need) because of illness and there is no alternative medicine that capable to do the cure, then he or she can proceed to the illegal thing by taking BV as therapy even though it will kill the bee right after the procedure. This is in line with the fiqh method of, "necessities render the prohibited permissible" (al-Zarqa', 1995).

From the standpoint of using BV as method of treatment, some practices and studies claimed it as capable to treat disease and safe to be used in small amounts (Ali, 2012). This is also allowed by Sharak because majority of scholars argued that animal venom should be used for treatment purposes as it is believed to have a capability to cure disease without causing harm (Ibn Qudamah, $1405 \mathrm{H})$

However, the researchers suggest that if the patients want to perform treatment with BVT method, they need to get an approval and guidance from the expert or specialist. This is because the original law of using venom for any benefit is illegal as stated in the hadith, but it is permissible based on urgent need in both darurah and hajah situations. Therefore, these are the requirements needed 
INTERNATIONAL JOURNAL OF ACADEMIC RESEARCH IN BUSINESS AND SOCIAL SCIENCES Vol. 10, No. 11, 2020, E-ISSN: 2222-6990 @ 2020 HRMARS

in order to meet the criteria for darurah and hajah situations; obtaining the consent and directive of a medical professional, no alternative medicine for the disease encountered, treatment only at the rate of need, and no allergy to the medicine (JAKIM, 2015). Therefore, BVT cannot be taken unless it has met all four of the requirements outlined. This is due to the high risk of treatment using the BVT method, and it has been reported to cause the death of a 55-year-old woman after undergoing the treatment (Vazquez-Revuelta \& Madrigal-Burgaleta, 2018). This is also in line with studies conducted by Zhang et al., (2018), Vazquez-Revuelta and Madrigal-Burgaleta (2018), Korosec et al., (2015) and Köhler et al., (2014) that stated BVT as having a potential to bring risks and negative effects to patients that could cause to fatality. This is because BVT is a traditional therapy method and has not yet been recognised as a modern therapy where the dosage content during the application is still uncertain, and there is no reliable and rigorous scientific evidence that proving BVT medicinal effectiveness (Zhang et al., 2018). Therefore, with the advice and approval of a specialist, patient will receive sufficient information about the BVT, regarding its appropriateness based on specific criteria such as allergy-free, dosage and appropriate content, age-appropriate, comparison with other medicines that are safer, and many others.

Figure 1: Islamic Treatment Ethics in Bee Venom Therapy (BVT)

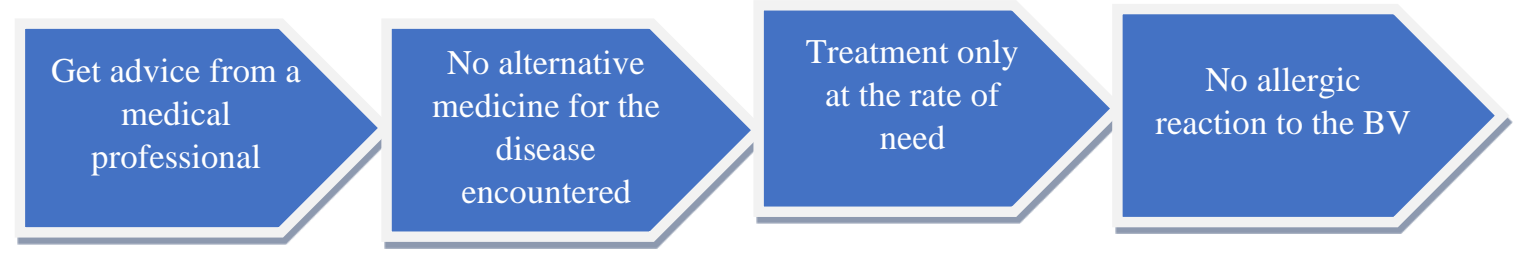

\section{Conclusion}

Although Islamic ethics treatment justify BVT as permissible to be used as a medicine, the permission is still relied on four ethics, which consisting of (i) get advice from a medical professional first, (ii) no alternative medicine for the disease encountered, (iii) treatment only at the rate of need, and (iv) no allergic reaction to the BV. These ethics are important to be followed because there is a report of a patient dying because of BVT. Besides, there are also other studies that show BVT as a method that can gives adverse side effects on patients who undergo the treatment. This study has limitations by solely focusing on the analysis of BVT practices from the ethical point of Islamic treatment. Thus, further research such as empirical study is recommended in order to obtain information from the experienced BVT practitioners.

\section{References}

Al-Bukhari, M. I. (1422H). Sahih al-Bukhari. Jiddah: Dar Tauq al-Najah.

Ali, M. A. A. S. M. (2012). Studies on Bee Venom and Its Medical Uses. Int J Adv Res Technol, 1(2), 6983.

Al-Mubarakfuri, A. (n.d.) Tuhfah al-Ahwadhi. Beirut: Dar al-Kutub.

Al-Nawawi, M. S. (n.d.). al-Majmu'. Jiddah: Maktabah al-Irsyad.

Al-Zarqa', A. M. (1995). Syarh al-Qawa'id al-Fiqhiyyah. Dimashq: Dar al-Qalam.

Blaauw, B. R., \& Isaacs, R. (2014). Flower Plantings Increase Wild Bee Abundance and the Pollination Services Provided to a Pollination-Dependent Crop. Journal of Applied Ecology, 51(4), 890898. 
INTERNATIONAL JOURNAL OF ACADEMIC RESEARCH IN BUSINESS AND SOCIAL SCIENCES

Vol. 10, No. 11, 2020, E-ISSN: 2222-6990 @ 2020 HRMARS

Daud, M. (1996). Ethics of Supervision. Kuala Lumpur: Utusan Publication.

Gatrad, A. R., \& Sheikh, A. (2001). Medical Ethics and Islam: Principles and Practice. Archives of Disease in Childhood, 84(1), 72-75.

Ibn Hanbal, M. (2001). Musnad. Beirut: Muassasah al-Risalah.

Ibn Qudamah, A. A. (1405H). al-Mughni. Beirut: Dar al-Fikr.

JAKIM. (2015). Garis Panduan Bersama Kawalan Ubat-Ubat Dalam Islam. See: http://www.islam.gov.my/rujukan/garis-panduan/52-garis-panduan-bersama-kawalan-ubatubat-dalam-islam (accessed on 29/12/2019).

Jasmi, K. M. (2012). Penyelidikan Kualitatif dalam Sains Sosial. Johor Bharu: Universiti Teknologi Malaysia.

Khairuldin, W. M. K. F. W., Anas, W. N. I. W. N., Embong, A. H., Hassan, S. A., Hanapi, M. S., \& Ismail, D. (2019). Ethics of Mufti in the Declaration of Fatwa According to Islam. Journal of Legal, Ethical and Regulatory Issues.

Köhler, J., Blank, S., Muller, S., Bantleon, F., Frick, M., Huss-Marp, J., ... \& Jakob, T. (2014). Component Resolution Reveals Additional Major Allergens in Patients with Honeybee Venom Allergy. Journal of Allergy and Clinical Immunology, 133(5), 1383-1389.

Korosec, P., Ziberna, K., Silar, M., Dezman, M., Smodis, C. N., Rijavec, M., ... \& Kosnik, M. (2015). Immunological and Clinical Factors Associated with Adverse Systemic Reactions During the Build-Up Phase of Honeybee Venom Immunotherapy. Clinical \& Experimental Allergy, 45(10), 1579-1589.

Mizrahi, A., \& Lensky, Y. (Eds.). (2013). Bee Products: Properties, Applications, and Apitherapy. Springer Science \& Business Media.

Orsolic, N. (2012). Bee Venom in Cancer Therapy. Cancer and Metastasis Reviews, 31(1-2), 173-194.

Park, H. J., Lee, S. H., Son, D. J., Oh, K. W., Kim, K. H., Song, H. S., ... \& Hong, J. T. (2004). Antiarthritic Effect of Bee Venom: Inhibition of Inflammation Mediator Generation by Suppression of NFKB through Interaction with the p50 Subunit. Arthritis \& Rheumatism, 50(11), 3504-3515.

Sahad, M. N., \& Asni, F. (2018). Free-Riderism Among Academicians: An Ethical of Islamic Perspective. Journal of Legal, Ethical and Regulatory Issues, 21(4), 1-6.

Shaharom, M. H., Ngah, A. C., Koon, S. T. M., Rahman, A. H. A., \& Sidi, H. (2008). Etika Perubatan Islam dan Isu-Isu Psikiatri. Kuala Lumpur: Dewan Bahasa dan Pustaka.

Shipp, J. L., Whitfield, G. H., \& Papadopoulos, A. P. (1994). Effectiveness of the Bumble Bee, Bombus Impatiens Cr. (Hymenoptera: Apidae), As A Pollinator of Greenhouse Sweet Pepper. Scientia Horticulturae, 57(1-2), 29-39.

Vazquez-Revuelta, P., \& Madrigal-Burgaleta, R. (2018). Death Due to Live Bee Acupuncture Apitherapy. J Investig Allergol Clin Immunol, 28(1), 45-46.

Yusof, R. (2004). Penyelidikan Sains Sosial. Kuala Lumpur: PTS Publication.

Zhang, S., Liu, Y., Ye, Y., Wang, X. R., Lin, L. T., Xiao, L. Y., ... \& Liu, C. Z. (2018). Bee Venom Therapy: Potential Mechanisms and Therapeutic Applications. Toxicon, 148, 64-73.

Zia, M., \& Muhammad, Z. (2017). Bee Sting of the Cornea. Journal of Bacha Khan Medical College, 1(2), 2-2. 